\title{
Evaluation of water pollution and source identification in Merbok River Kedah, Northwest Malaysia
}

\author{
Haidr Msahir Ateshan a, b, Rosmilah Misnan a, ${ }^{,}$, Som Cit Sinang a, Isa Baba Koki c \\ a Department of Biology, Faculty of Science and Mathematics, Universiti Pendidikan Sultan Idris, 35900 Tanjung Malim, Perak, Malaysia. \\ b Biology department, Mohsen Al-Hakim School, Thi-Qar Education Directorate, Nasiriyah 64001, Iraq \\ c Department of Chemistry, Yusuf Maitama Sule University Kano, PMB 3220 Kano Nigeria \\ *Corresponding author: rosmilah@fsmt.upsi.edu.my
}

\section{Article history}

Received 29 August 2019

Revised 22 December 2019

Accepted 29 January 2020

Published Online 18 August 2020

\begin{abstract}
This study investigates the temporal water quality variations and pollution sources identification in Merbok River using principal component analysis. The variables analyzed include $\mathrm{As}, \mathrm{Cd}, \mathrm{Pb}, \mathrm{Fe}, \mathrm{Cr}$, $\mathrm{Mn}, \mathrm{Zn}, \mathrm{Ni}, \mathrm{Ca}, \mathrm{Mg}, \mathrm{Na}, \mathrm{K}, \mathrm{NH}_{4}, \mathrm{~F}, \mathrm{Cl}, \mathrm{Br}, \mathrm{NO}_{2}, \mathrm{NO}_{3}, \mathrm{SO}_{4}, \mathrm{PO}_{4}, \mathrm{pH}, \mathrm{BOD}$, DO, COD, turbidity, and salinity. These variables were analyzed using inductively coupled plasma mass spectrometry, ion chromatography, and YSI multiprobe. Principal component analysis (PCA) was utilized to evaluate the variations of the most significant water quality parameters and identify the probable source of the pollutants. From the results of PCA, $86 \%$ of the total variations were observed in the water quality data with strong dominance of toxic heavy metals $(\mathrm{As}, \mathrm{Pb}$, and $\mathrm{Cr}$ ), parameters associated with industrial discharge, domestic inputs, overland runoff $\left(\mathrm{NH}_{4}, \mathrm{pH}, \mathrm{BOD}, \mathrm{DO}, \mathrm{COD}\right)$, agrochemicals $\left(\mathrm{NO}_{2}, \mathrm{NO}_{3}, \mathrm{SO}_{4}\right.$, $\left.\mathrm{PO}_{4}\right)$, and weathering of basement rocks $(\mathrm{Ca}, \mathrm{Mg}, \mathrm{Cl}, \mathrm{F}, \mathrm{K}$, and $\mathrm{Na}$ ). Most of these parameters were present in concentrations exceeded the reference standards limits used in this study, indicating pollution of the river water. Together with the presence of microbial contamination, the results suggest potential human health risk due to water uses, fish and shellfish consumption. Moreover, the results revealed that anthropogenic activities and weathering were the main sources of pollutants in Merbok River.
\end{abstract}

Keywords: Multivariate analysis, water quality, pollution, principal component analysis, river

\section{INTRODUCTION}

Sources of water for agricultural and drinking purposes in Malaysia are mostly from rivers, streams, and lakes (Sharip and Jusoh, 2010). However, rapid industrialization and continuous increase in population growth impacted negatively on the quality of surface water. These resulting in the degradation of aquatic environments, and hinder the growth of organisms (Mearns et al., 2015). To improve the quality of surface water proper environmental management should be implemented.

There is a myriad of factors related to both anthropogenic and natural sources influence the quality of surface water. The contamination of rivers with toxic elements is one of the major issues of concern affecting agricultural areas and the health of several neighboring communities due to the frequent use of agrochemicals such as fertilizers, herbicides, and nutrients (Ahmad et al., 2015a). These can lead to a rapid increase in concentrations of toxic elements in the water. Hence, there is a need for further understanding of variations in water characteristics especially on metals and non-metals, and the identification of the possible sources of pollution to provide detailed and precise information on the water quality status (Juahir et al., 2011).

Proper evaluation of water pollution and identification of the pollutant sources has been described as one of the environmental challenges because of many parameters or variables involved resulting in complex treatment of data (Simeonov et al., 2003; Zain et al., 2016). Multivariate statistical analysis such as principal component analysis
(PCA) identifies the pollutant sources, and explains the variations among the parameters with respect to the sampling sites or periods. PCA is an unsupervised pattern recognition technique which provides information on the most significant parameter(s) that explain the major variation in the data set, it excludes less significant parameters with minimum loss of information and identifies the unobservable, latent pollution sources. PCA explain the possible factors that are responsible for the variation in surface water quality (Koki et al., 2017).

In the present study, analysis of metals and non-metals in water from Merbok River was carried out to evaluate the pollution level and environmental impact on quality of the water, and to identify the possible sources of the pollutants. This would assist in evaluating the quality status of the river for proper utilization and its possible effect on aquatic organisms.

\section{EXPERIMENTAL}

\section{The study area}

This study was conducted in Sungai Petani $\left(5^{\circ} 39^{\prime} \mathrm{N} 100^{\circ} 30^{\prime} \mathrm{E}\right)$, Kuala Muda District, Kedah, Malaysia (Fig. 1). Sungai Petani is located about $35 \mathrm{~km}$ from Penang in the northern part of Peninsular Malaysia. The population of this city is estimated to be 443,458 according to 2010 census data report. Water samples were obtained from Merbok River which traces its main sources to Mount Jerai and Sungkap forest. The river is about $2.5 \mathrm{~km}$ wide and is known as the historical river of Lembah Bujang. Sungai Petani was heavily industrialized dating back to 1990 
by Japanese investors producing textile materials, television tubes, and semiconductors among many other products. Due to the regular and frequent agricultural practices in the study area, different brands of fertilizers were used for the purpose of reclaiming land and improving the yield (Ahmad et al., 2015b).

\section{Water sampling and analysis}

Water samples were collected from three locations along the Merbok River at three months interval which were in August and November 2017, February 2018 and May 2018. The samples were collected from a $25 \mathrm{~cm}$ depth below the water surface and subsequently preserved by the addition of a few drops of acid to $\mathrm{pH}<2$ to prevent metals sedimentation in the container surface (Koki et al., 2018). The preserved samples were then transported to the laboratory in iceboxes at a temperature of $4^{\circ} \mathrm{C}$ for an elemental analysis. Physico-chemical parameters such as a $\mathrm{pH}$, temperature, $\mathrm{DO}$, salinity, and turbidity were assessed in the field using portable YSI multiprobe (YSI550A) and salinity/temperature meter (EC170). Biological oxygen demand (BOD) and chemical oxygen demand (COD) were measured in the laboratory following standard procedures (APHA, 1995). The heavy metals $(\mathrm{Cr}$, $\mathrm{Zn}, \mathrm{Mn}, \mathrm{Cd}, \mathrm{Fe}, \mathrm{Ni}, \mathrm{As}$, and $\mathrm{Pb}$ ) and cations ( $\mathrm{Li}, \mathrm{Na}, \mathrm{NH}_{4}, \mathrm{~K}, \mathrm{Mg}$, and Ca) were analyzed using ICP-MS instrument ELAN 9000 DRC-e (Perkin Elmer, Axial field technology, USA). Moreover, the anions $(\mathrm{Cl}$, $\mathrm{NO}_{2}, \mathrm{Br}, \mathrm{NO}_{3}, \mathrm{SO}_{4}, \mathrm{PO}_{4}$ ) were analyzed using Ion-Chromatography (ICS2100, Thermo Fisher Scientific Inc. USA). The calibration stock solution (multi element) of $10 \mathrm{mg} / \mathrm{L}$ for $\mathrm{Pb}, \mathrm{Cd}, \mathrm{As}, \mathrm{Mn}, \mathrm{Zn}, \mathrm{Ni}$ and $\mathrm{Cr}$ and 1,000 mg/L for $\mathrm{Ca}, \mathrm{Mg}, \mathrm{Fe}, \mathrm{Li}, \mathrm{NH}_{4}$ and $\mathrm{Na}$ (Agilent Technologies, Newcastle). For the Ion Chromatography (IC), a $1000 \mathrm{mg} / \mathrm{L}$ multi element calibration stock solution of the selected anions was prepared by the appropriate dilution. In this analysis, blank samples were analyzed after every five samples for proper validation. The analyses of all samples were carried out in triplicates and the results were expressed as the mean and standard deviation in $\mathrm{mg} / \mathrm{L}$.

\section{Elemental analysis}

The preserved water samples in triplicates were filtered using 70 $\mathrm{mm}$ filter paper (Advantec) before the elemental analysis. The filtered samples were analyzed using ICP-MS and IC for the heavy metals, metals, and non-metals. The ICP-MS operating conditions of the instruments were monitored and maintained to keep the sensitivity of the instrument. The IC provides high sensitivity and multiple elemental determinations in a single run. $\mathrm{Li}, \mathrm{NO}_{2}$, and $\mathrm{Br}$ were not detected in all the water samples analyzed and therefore not further considered, while $\mathrm{F}$ was not detected in some of the water samples analyzed.

\section{Bacterial analysis}

The water samples collected for bacterial study were immediately preserved in dark cooled boxes, and processed within $6 \mathrm{hr}$ of the sampling. The technique applied for the Fecal coliform (FC) and E. coli (EC) determination was the most-probable-number (MPN) approach using five tubes per water sample dilution $\left(10^{-1}\right.$ to $\left.10^{-7}\right)$. The media was placed in $10 \mathrm{ml}$ bottles and inverted Durham tubes were inoculated with $1 \mathrm{ml}$ volumes of the respective dilutions. The bottles were incubated at $37^{\circ} \mathrm{C}$ in a dry incubator; $\mathrm{FC}$ bottles were incubated at $44^{\circ} \mathrm{C}$ in a water bath. The production of gas and turbidity within $48 \mathrm{hr}$ indicates a positive response. For the simultaneous detection of FC and EC, surface plate technique was used with Chromocult coliform agar (CCA) (APHA, 1995; Frampton et al., 1988).

\section{Statistical analysis}

Statistical analysis (mean and standard deviation), and one-way ANOVA were carried out using MS Excel 2010. ANOVA was applied to study the differences in the parameter levels for the periods under study. The statements reported in this study were at $p<0.05$ levels. Multivariate statistical analysis including PCA was carried out using JMP Pro12.

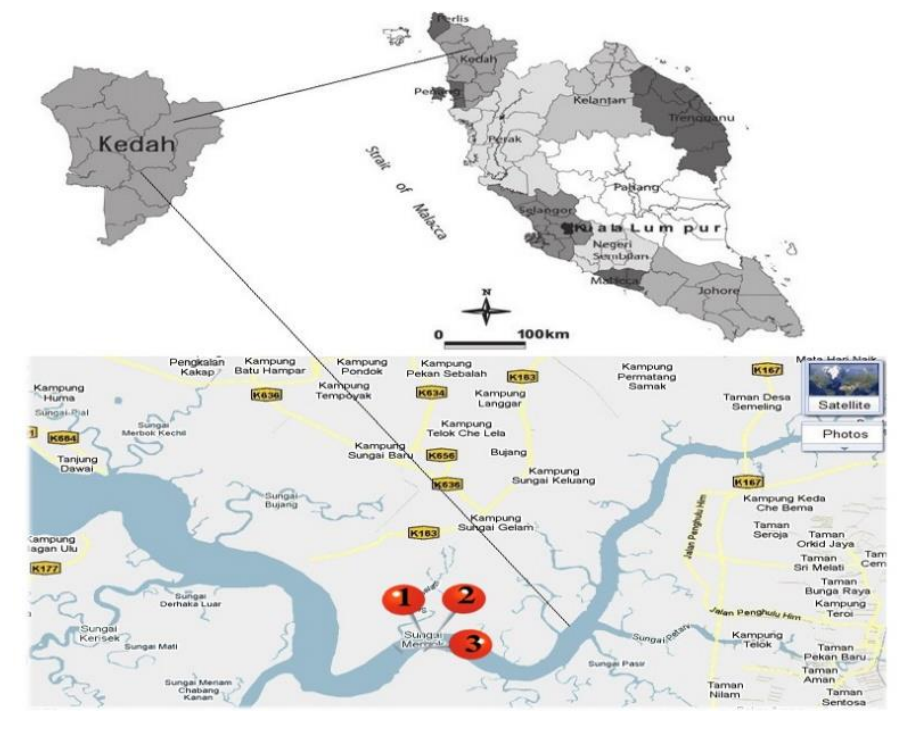

Fig. 1 Map of the study area showing location of Merbok River, Kedah Malaysia

\section{RESULTS AND DISCUSSION}

\section{Assessment of water quality in Merbok River}

The comparison of variations in metals and physico-chemical parameters in river water with Malaysia's interim national water quality standard (INWQS) and World Health Organization (WHO, 2004) guideline is presented in Table 1. The results revealed notable spatial variations in the studied parameters which were associated with anthropogenic activities and natural background sources. A significant difference $(p<0.05)$ was observed in the parameter levels at the sampling periods. Among the metals and heavy metals under study, $\mathrm{Cr}$, $\mathrm{As}, \mathrm{Pb}$, and $\mathrm{NH}_{4}$ exceeded the reference limits in some of the periods under study.

Elevated Cr concentrations above WHO and INWQS values of 0.5 mg/L were observed in Aug and Nov 2017, and May 2018. This could be due to high volume of rainfall and variations in surface runoff from industrial pollution sources (Alsaffar et al., 2016), high flow of surface water gives more deposition of metals from its sources (Nor Farhanna et al., 2015). Sources of $\mathrm{Cr}$ in the environment could be linked to metallurgy, and wood preservation (Butera et al., 2015; Chen et al., 2016). Ahmad et al. (2015a) reported the presence of heavy metals including $\mathrm{Cr}$ in Merbok river and linked its sources to industrial activities. Fig. 2 shows the highest $\mathrm{Cr}$ level $(1.17 \mathrm{mg} / \mathrm{L})$ in the river water in Aug 2017. Cr is carcinogenic, and other health effects include disorders such as gastrointestinal, renal, cardiovascular, hepatic, and hematological (ATSDR, 2013).

$\mathrm{Fe}$ concentration of $2.90 \mathrm{mg} / \mathrm{L}$ which exceeded the recommended limit of $1.0 \mathrm{mg} / \mathrm{L}$ was observed in Feb 2018. Other than the fact that $\mathrm{Fe}$ is the second most abundant element in the earth crust, other possible sources of $\mathrm{Fe}$ in the water could be linked to industrial and agricultural inputs (Hossain, 2013). High Fe concentrations in Feb 2018 could be associated with industrial sources. Mansor et al. (2014) reported high rate of land modifications to industrial sites in Sungai Petani for economic gains, which have a direct negative impact on the environment including water resources. Similarly, Haris et al. (2007) identified the development and land use activities along the river catchment area as the cause of high pollutant load discharged into the river.

As and $\mathrm{Pb}$ were found to be within the INWQS and WHO reference standards, and were only detected in August 2017. The health effects of As include cancer, digestive, gastrointestinal and central nervous disorder, cardiovascular disturbances, and death (Mandal and Suzuki, 2002). $\mathrm{Pb}$ is poisonous, and its effects include brain and nervous system resulting in low intelligent quotient (IQ) (Sibal and Espino, 2018). 
Fig. 3 shows $\mathrm{NH}_{4}$ concentrations of 121 1nd $123 \mathrm{mg} / \mathrm{L}$ which were recorded in Aug and Nov 2017, respectively. These concentrations were far above the reference limits of 0.3 and $1.5 \mathrm{mg} / \mathrm{L}$, respectively, for INWQS and WHO. Sources of $\mathrm{NH}_{4}$ in water include fertilizer and animal excreta associated with rainfall flow down to the river. Ammonium is toxic, and its presence in surface water beyond the recommended limits signifies pollution and threat to human health ( $\mathrm{Lp}$ et al., 2001). Ismai'l et al. (2015) linked the elevated $\mathrm{NH}_{4}$ and other nutrients concentrations along Merbok River and its catchments to the effects of urbanization and population explosion. Kamrudzaman et al. (2012) highlighted the contamination of Merbok River water, in which the contribution of point sources was reported to be higher compared to non-point source of pollution. Similarly, several human-induced activities near Merbok River such as unregulated sewage discharge could also result in deterioration of water quality (Haris et al., 2007). High concentrations of $\mathrm{Na}$ were observed in all the months under study compared to other cations analyzed. Since Merbok River has tributaries linked to the ocean (Kamrudzaman et al., 2012), it was reported that most important exchange between river water, ocean water, and the sediment is the release of $\mathrm{Ca}$ and the uptake of $\mathrm{Na}$ (Cerling et al., 1989). Similarly, weathering and dissolution of basement rocks release $\mathrm{Na}$ and raise its concentrations in the surface water (Koki et al., 2017; Ruiz-Agudo et al., 2017).

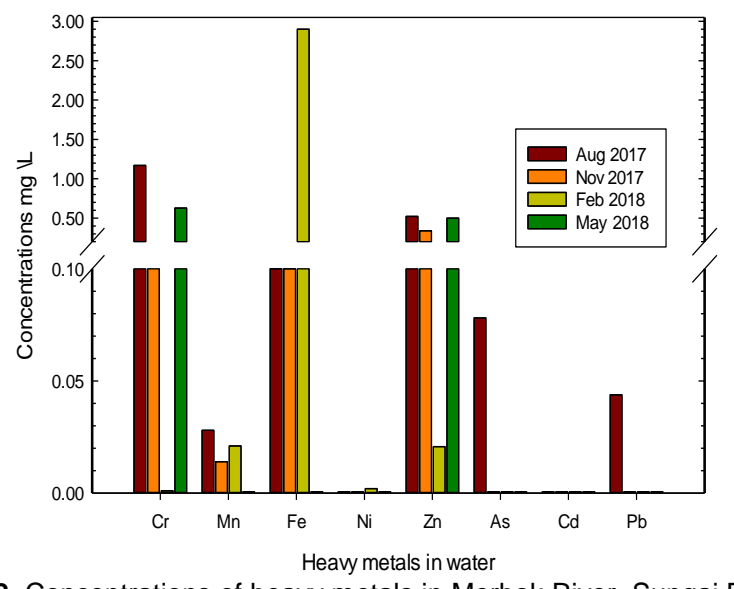

Fig 2. Concentrations of heavy metals in Merbok River, Sungai Petani.

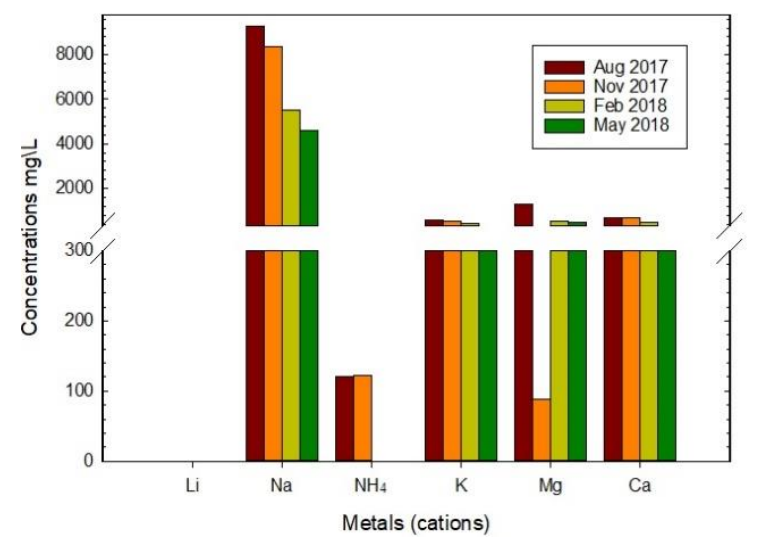

Fig 3. Concentrations of metals in Merbok River, Sungai Petani
The presence of high levels of $\mathrm{F}$ and $\mathrm{Cl}$ in the river water signifies contamination. The concentrations of F were 101 and $107 \mathrm{mg} / \mathrm{L}$ for Aug and Nov 2017, but not detected in other observed months. These values surpass the reference limits of $1.5 \mathrm{mg} / \mathrm{L}$ (DOE, 2012; WHO, 2004). The elevated concentrations of $\mathrm{F}$ could be associated with land use activities such as industrial discharges, commercial, and agricultural practices (Kamrudzaman et al., 2012). It has been established that besides the weathering processes, aluminium production, Phosphate fertilizer, and pesticides and herbicides containing Flouride are sources of $F$ in surface water (Fuge, 2018). The use of Phosphate fertilizers introduces F in agricultural lands which is transported by the surface runoff (Brindha and Elango, 2011). The health effects of $F$ include impaired human growth, mottled teeth, poor appetite and low food intake (Wang et al., 2011).

$\mathrm{Cl}$ concentrations were above the recommended values for all the months under study with significant level in Feb 2018 as shown in Fig. 4. High $\mathrm{Cl}$ concentrations in river water is likely to originate from fertilizers, septic tank, and domestic effluents. $\mathrm{Cl}$ concentrations beyond permissible limits increase the effect of heart and kidney diseases (WHO, 1997; Mor et al., 2006). The levels of $\mathrm{NO}_{3}, \mathrm{SO}_{4}$, and $\mathrm{PO}_{4}$ were all above the reference standards in the study periods. The source of $\mathrm{NO}_{3}$ could be associated with the discharge of waste water and leachate. Concentration of $\mathrm{SO}_{4}$ ranged from 1234 to $11084 \mathrm{mg} / \mathrm{L}$ were above the permissible limits, and the highest level was in Feb 2018. $\mathrm{SO}_{4}$ are usually leached out to surface water, or released from farmlands due to the application of fertilizer (MOR et at al., 2006). $\mathrm{PO}_{4}$ in the river water ranged from 36 to $338 \mathrm{mg} / \mathrm{L}$ with the highest concentration in May 2018. Sources of $\mathrm{PO}_{4}$ include agricultural runoff, erosion and industrial discharges (Chaurasia and Pandey, 2007).

The acidity of the river was found to be within the INWQS and WHO ranges of 6.5-8.5 and 6.5-8.0, respectively, in all the studied periods (DOE 2012; WHO 2004), except in Nov 2017 with pH value of 6.32 slightly lower than the minimum level as shown in Fig. 5. Both DO and BOD were not within the reference limits of the standard values in the periods under study. This is an indication of contamination of the river water by organic matter which could result in the death of aquatic organism (Koki et al., 2017). Sources of high organic matter in surface water could be linked to urban runoff and other anthropogenic activities along the river bank. The levels of COD indicated the presence of chemically oxidizable pollutants in water and were found to be in the ranges of 30 to $92 \mathrm{mg} / \mathrm{L}$ which were beyond the INWQS and WHO standard values of 25 and $10 \mathrm{mg} / \mathrm{L}$ respectively. Significant COD value of $92 \mathrm{mg} / \mathrm{L}$ was recorded in May 2018. High COD value in the river water depletes the oxygen levels, and could be linked to discharge from chemical industries and roof runoff among others (Ahmed 2017). The levels of turbidity in the river water for the period under study was in the range of 7.04 to 9.60 which are less than INWQS of $50 \mathrm{NTU}$, but higher than WHO standard limit of 5.0 NTU.

For the bacterial analysis, presence of coliform and $E$. coli in the water indicates contamination of the surface water with pathogens which could be termed as pollution and unsafe. Table 2 reveals that 1011.20 count $/ 100 \mathrm{ml}$ was the significant value obtained in May 2018 which is higher than INWQS value of 100 count $/ 100 \mathrm{ml}$. The presence of high bacterial cell count could be linked to the discharge of sewage and leaching of animal manure and septic tanks (Jamieson et al., 2003). Table 2 shows that other months under study revealed levels of coliform below the reference limit. E. coli was detected in all the river water samples analyzed which indicates contamination with fecal substances that contain microorganisms such as parasites, viruses, and bacteria (Feng et al., 2002). 


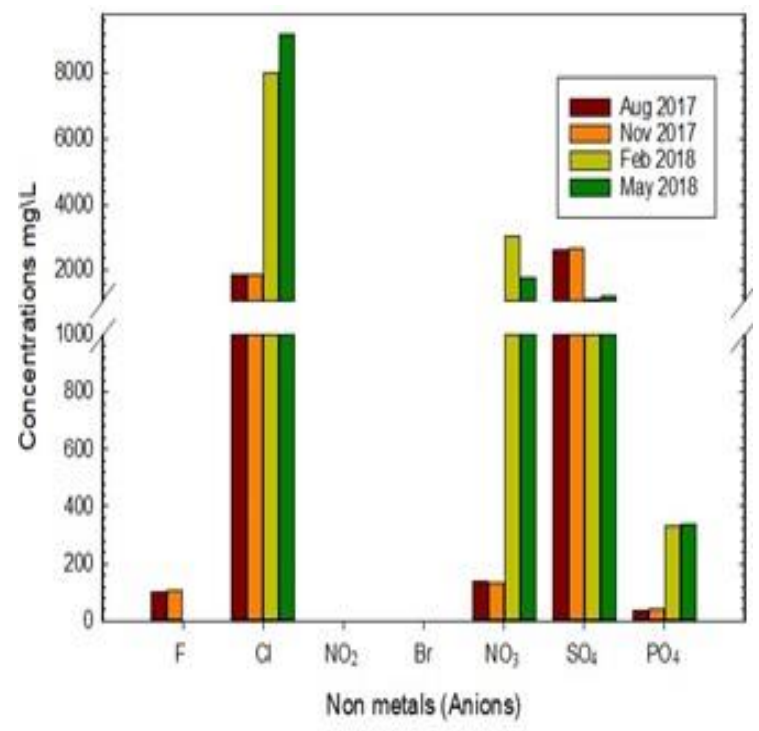

Fig 4. Concentrations of Non- metals in Merbok River, Sungai Petani

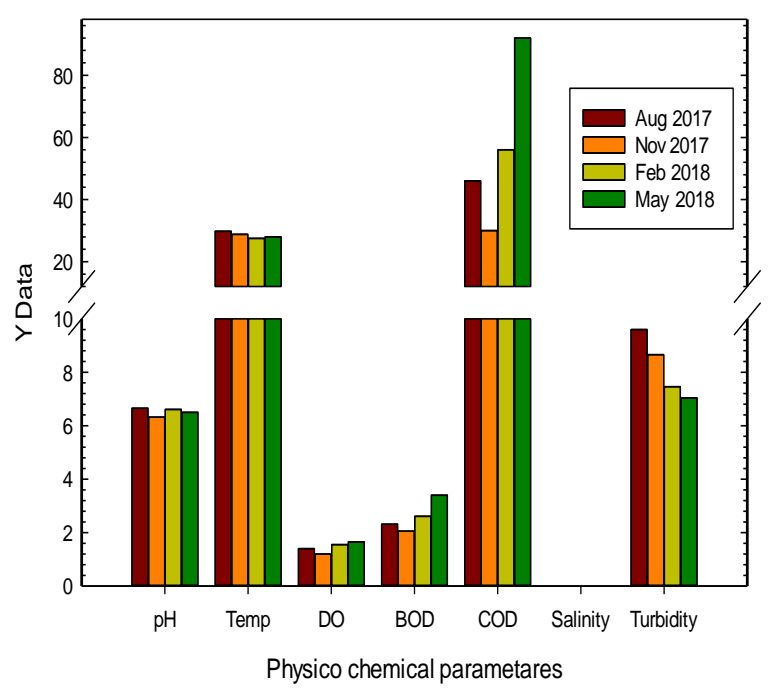

Fig 5. Levels of Physico chemical parameters in Merbok River, Sungai Petani (All parameters in $\mathrm{mg} / \mathrm{L}$ except $\mathrm{pH}$ no unit, temp in ${ }^{\circ} \mathrm{C}$, turbidity in NTU)

\section{Principal component analysis and determination of pollution sources}

The variations in parameter levels and distribution are precisely explored using PCA, which utilizes three principal components (PCs) based on eigen value > 1 (Koki et al., 2017). The first PC (PC1) contains most of the information explaining the major variation in the entire data set. In the present study, PC1 and PC2 accounted for $48.8 \%$ and $22.4 \%$ respectively of the total variance as shown in Fig. 7. The PC loadings (Table 3 ) revealed that $\mathrm{PC} 1$ contained positively correlated parameters such as $\mathrm{Cr}, \mathrm{Zn}, \mathrm{As}, \mathrm{Pb}, \mathrm{F}, \mathrm{NH}_{4}, \mathrm{Na}, \mathrm{Mg}, \mathrm{K}$, Temp, salinity, and turbidity. This $\mathrm{PC}$ explain pollution of the river water with heavy metals which could be from industrial discharges into Merbok river (Ahmad et al., 2015a), runoff from agricultural sites (Haris and Omar, 2007; Kozaki et al., 2016), and leaching of minerals from rocks due to weathering which influences the salinity and turbidity of the river water (Low et al., 2016). Furthermore, negatively correlated variables were also identified including $\mathrm{pH}, \mathrm{NO}_{3}, \mathrm{SO}_{4}, \mathrm{PO}_{4}, \mathrm{DO}, \mathrm{BOD}, \mathrm{COD}$ which revealed pollution due to organic matter, domestic effluent and the surface runoff from agrochemicals (Juahir et al., 2011). Haris and Omar (2007) identified urban runoff to the river surface water, which is accompanied by the direct or unregulated sewage discharge into the river. $\mathrm{PC} 2$ shows strong positive loadings on $\mathrm{Mn}, \mathrm{Fe}, \mathrm{Ni}, \mathrm{Cl}, \mathrm{NO}_{3}, \mathrm{SO}_{4}$, and negative loading on BOD and COD signifying natural sources of the metals, and anthropogenic input along the river water. PC3 shows strong positive loading on $\mathrm{Cr}, \mathrm{As}, \mathrm{Pb}$ and $\mathrm{Mg}, \mathrm{pH}$, and $\mathrm{DO}$ indicating the presence of toxic heavy metals originating from industrial discharges, and influence of dissolution of rocks and organic matter influx.

Analyzing the sampling periods by comparing scores and loadings in Fig. 6, it was observed that Merbok River water was more contaminated with heavy metals (As, Cr and Pb) in Aug and Nov 2017. The water quality in these periods strongly violates the reference standards used in this study (DOE 2012; WHO 2004). As Malaysia records high volume of rainfall in August and November (Wong et al., 2009), surface runoffs could be the major contributing factor to the elevated contaminant levels (Pereira and Hostettler, 1993; Happonen et al., 2016). May 2018 is seen to experience high levels of pollution due to oxygen-consuming pollutants from industries and other human activities, while Feb 2018 was associated with contaminants linked to agricultural activities specifically fertilizer and surfactants. This shows variations in water quality at different periods under study which could strongly be attributed to anthropogenic activities and dissolution of rock minerals due to weathering processes.

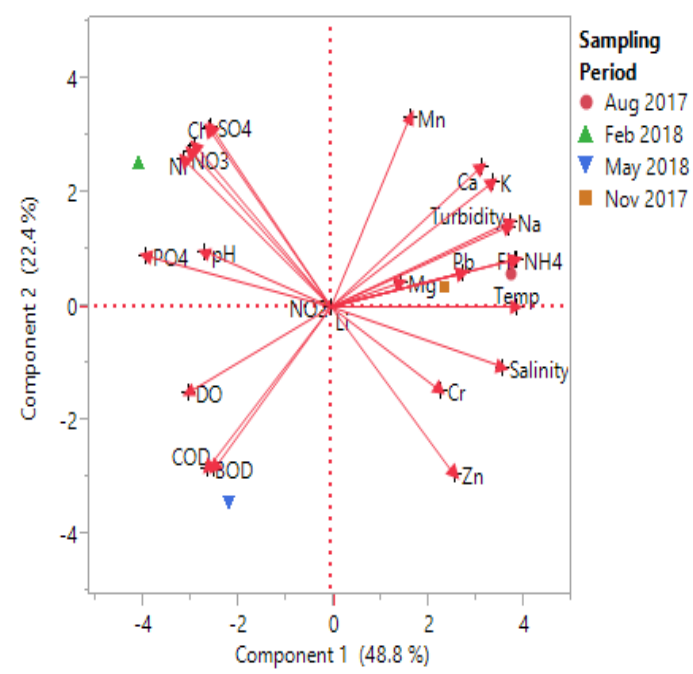

Fig 6: PCA biplot of the analyzed parameters in Merbok River, Sungai Petani 
Table 1. Parameters concentrations in Merbok River Sungai Petani.

\begin{tabular}{|c|c|c|c|c|c|c|c|}
\hline & $\begin{array}{l}\text { Aug } \\
2017\end{array}$ & $\begin{array}{l}\text { Nov } \\
2017\end{array}$ & $\begin{array}{l}\text { Feb } \\
2018\end{array}$ & $\begin{array}{l}\text { May } \\
2018\end{array}$ & $\begin{array}{c}\text { Mean } \\
\pm \\
\text { SD }\end{array}$ & INWQS & WHO \\
\hline $\mathrm{Cr}$ & 1.17 & 0.121 & 0.001 & 0.63 & $\begin{array}{c}0.4800 \\
\pm \\
0.4627\end{array}$ & 0.05 & 0.05 \\
\hline Mn & 0.03 & 0.014 & 0.021 & 0.50 & $\begin{array}{c}0.0160 \\
\pm \\
0.0101\end{array}$ & 0.10 & 0.4 \\
\hline $\mathrm{Fe}$ & 0.10 & 0.100 & 2.90 & 0.50 & $\begin{array}{c}0.7751 \\
\pm \\
1.2275\end{array}$ & 1.00 & 0.3 \\
\hline $\mathrm{Ni}$ & ND & ND & 0.002 & ND & $\begin{array}{c}0.0009 \\
\pm \\
0.0007\end{array}$ & 0.05 & 0.02 \\
\hline $\mathrm{Zn}$ & 0.52 & 0.339 & 0.021 & 0.50 & $\begin{array}{c}0.3456 \\
\pm \\
0.2003\end{array}$ & 5.00 & 3.0 \\
\hline As & 0.08 & ND & ND & ND & $\begin{array}{c}0.0199 \\
\pm \\
0.0336\end{array}$ & 0.05 & 0.01 \\
\hline Cd & ND & ND & ND & ND & ND & 0.01 & 0.003 \\
\hline $\mathrm{Pb}$ & 0.04 & ND & ND & ND & $\begin{array}{c}0.0113 \\
\pm \\
0.0187\end{array}$ & 0.05 & 0.01 \\
\hline $\mathrm{Li}$ & ND & ND & ND & ND & - & - & 0.01 \\
\hline $\mathrm{Na}$ & 9279 & 8376 & 5515 & 4608 & $\begin{array}{c}6944 \\
\pm \\
1936\end{array}$ & - & . \\
\hline $\mathrm{NH}_{4}$ & 121 & 123 & ND & ND & $\begin{array}{c}122 \\
\pm \\
1\end{array}$ & 0.3 & 1.5 \\
\hline K & 574 & 524 & 414 & 313 & $\begin{array}{c}456 \\
\pm \\
100\end{array}$ & - & \\
\hline Mg & 1279 & 88 & 506 & 474 & $\begin{array}{c}587 \\
\pm \\
432 \\
\end{array}$ & - & \\
\hline $\mathrm{Ca}$ & 686 & 680 & 493 & 300 & $\begin{array}{c}587 \\
\pm \\
432 \\
\end{array}$ & - & \\
\hline $\mathbf{F}$ & 101 & 107 & ND & ND & $\begin{array}{c}104 \\
\pm \\
3\end{array}$ & 1.5 & 1.5 \\
\hline $\mathrm{Cl}$ & 18499 & 18587 & 80314 & 9184 & $\begin{array}{c}9184 \\
\pm \\
28357 \\
\end{array}$ & 200 & 5.0 \\
\hline $\mathrm{NO}_{2}$ & ND & ND & ND & ND & - & 0.4 & 3.0 \\
\hline $\mathrm{Br}$ & ND & ND & ND & ND & - & 0.025 & 0.01 \\
\hline $\mathrm{NO}_{3}$ & 139 & 132 & 30318 & 1767 & $\begin{array}{c}8089 \\
\pm \\
12851\end{array}$ & 7.0 & 50 \\
\hline $\mathrm{SO}_{4}$ & 2627 & 2691 & 11084 & 1234 & $\begin{array}{c}4409 \\
\pm \\
3897 \\
\end{array}$ & 250 & 250 \\
\hline $\mathrm{PO}_{4}$ & 36 & 44 & 332 & 338 & $\begin{array}{c}188 \\
\pm \\
147 \\
\end{array}$ & 0.2 & 0.3 \\
\hline pH & 6.65 & 6.32 & 6.61 & 6.50 & $\begin{array}{c}6.52 \\
\pm \\
0.13 \\
\end{array}$ & $\begin{array}{c}6.5 \\
- \\
8.5 \\
\end{array}$ & $\begin{array}{c}6.5 \\
- \\
8.0 \\
\end{array}$ \\
\hline Temp & 29.8 & 28.8 & 27.5 & 28.0 & $\begin{array}{c}28.52 \\
\pm \\
0.87\end{array}$ & - & \\
\hline DO & 1.4 & 1.2 & 1.55 & 1.65 & $\begin{array}{c}1.45 \\
\pm \\
0.17 \\
\end{array}$ & $5-7$ & $5-6$ \\
\hline BOD & 2.31 & 2.05 & 2.61 & 3.4 & $\begin{array}{c}2.59 \\
\pm \\
0.5065\end{array}$ & 3.0 & 3.0 \\
\hline COD & 46 & 30 & 56 & 92 & $\begin{array}{c}56 \\
\pm \\
22.76\end{array}$ & 25 & 10 \\
\hline Sal. & 0.01 & 0.014 & 0.011 & $\begin{array}{c}0.01 \\
2\end{array}$ & $\begin{array}{c}0.012 \\
\pm \\
0.001\end{array}$ & 1.0 & \\
\hline Turb. & 9.60 & 8.66 & 7.46 & 7.04 & $\begin{array}{c}8.19 \\
\pm \\
1.008\end{array}$ & 50 & 5.0 \\
\hline
\end{tabular}

Note: All parameters are in $\mathrm{mg} / \mathrm{L}$ except turbidity, temp and $\mathrm{pH}$,

in NTU, ${ }^{\circ} \mathrm{C}$ and no unit, respectively. ND = Not detected
Table 2. Results of Bacterial analysis of Merbok River, Sungai Petani.

\begin{tabular}{|c|c|c|c|c|c|}
\hline & $\begin{array}{l}\text { Aug } \\
\mathbf{2 0 1 7}\end{array}$ & $\begin{array}{l}\text { Nov } \\
\mathbf{2 0 1 7}\end{array}$ & $\begin{array}{l}\text { Feb } \\
\mathbf{2 0 1 8}\end{array}$ & $\begin{array}{l}\text { May } \\
\mathbf{2 0 1 8}\end{array}$ & INWQS \\
\hline Coliform & 8.30 & 2.10 & 73.30 & 1011.20 & 100 count/100 ml \\
\hline E. coli & $<1$ & 1.00 & $<1$ & 29.80 & $\begin{array}{c}\text { Non-detectable } \\
\text { per } 100 \mathrm{ml}\end{array}$ \\
\hline
\end{tabular}

Table 3: Result of the principal component analysis of the selected parameters

\begin{tabular}{cccc}
\hline Variables & PC1 & PC2 & PC3 \\
\hline $\mathrm{Cr}$ & $\mathbf{0 . 5 7 0 1 1}$ & -0.36623 & $\mathbf{0 . 7 3 5 4 3}$ \\
$\mathrm{Mn}$ & 0.41059 & $\mathbf{0 . 8 2 7 2 6}$ & 0.38348 \\
$\mathrm{Fe}$ & $-\mathbf{0 . 7 0 7 0 5}$ & $\mathbf{0 . 7 0 1 9 1}$ & 0.08606 \\
$\mathrm{Ni}$ & $\mathbf{- 0 . 7 2 9 5 0}$ & $\mathbf{0 . 6 7 7 9 8}$ & 0.09041 \\
$\mathrm{Zn}$ & $\mathbf{0 . 6 3 8 7 3}$ & $\mathbf{- 0 . 7 2 7 1 7}$ & 0.25150 \\
$\mathrm{As}$ & $\mathbf{0 . 6 8 3 3 7}$ & 0.14832 & $\mathbf{0 . 7 1 4 8 5}$ \\
$\mathrm{Pb}$ & $\mathbf{0 . 6 8 3 3 7}$ & 0.14832 & $\mathbf{0 . 7 1 4 8 5}$ \\
$\mathrm{F}$ & $\mathbf{0 . 9 5 7 3 0}$ & 0.20634 & -0.20250 \\
$\mathrm{Cl}$ & $\mathbf{- 0 . 6 3 3 2 4}$ & $\mathbf{0 . 7 7 0 7 0}$ & 0.07100 \\
$\mathrm{NO}$ & $\mathbf{- 0 . 7 6 3 0 2}$ & $\mathbf{0 . 6 3 9 0 2}$ & 0.09723 \\
$\mathrm{SO}$ & $\mathbf{0 . 6 2 2 7 6}$ & $\mathbf{0 . 7 7 9 7 8}$ & 0.06422 \\
$\mathrm{PO}$ & $\mathbf{- 0 . 9 6 7 5 4}$ & 0.22273 & 0.11941 \\
$\mathrm{Na}$ & $\mathbf{0 . 9 2 9 0 5}$ & 0.36985 & 0.00874 \\
$\mathrm{NH}$ & $\mathbf{0 . 9 6 3 3 3}$ & 0.20768 & -0.16992 \\
$\mathrm{Mg}$ & 0.36080 & 0.10566 & $\mathbf{0 . 9 2 6 6 4}$ \\
$\mathrm{Ca}$ & $\mathbf{0 . 7 8 1 7 3}$ & $\mathbf{0 . 6 1 0 0 8}$ & -0.12927 \\
$\mathrm{~K}$ & $\mathbf{0 . 8 4 0 2 1}$ & $\mathbf{0 . 5 4 1 5 6}$ & 0.02759 \\
$\mathrm{pH}$ & $\mathbf{- 0 . 6 5 7 1 6}$ & 0.24155 & $\mathbf{0 . 7 1 4 0 0}$ \\
$\mathrm{Temp}$ & $\mathbf{0 . 9 6 5 4 6}$ & 0.00078 & 0.26054 \\
$\mathrm{DO}$ & $-\mathbf{0 . 7 4 5 5 0}$ & -0.37353 & $\mathbf{0 . 5 5 2 0 1}$ \\
$\mathrm{BOD}$ & $\mathbf{- 0 . 6 4 1 6 4}$ & $\mathbf{- 0 . 7 0 2 1 5}$ & 0.30868 \\
$\mathrm{COD}$ & $\mathbf{- 0 . 6 0 7 0 2}$ & $\mathbf{- 0 . 7 0 2 6 5}$ & 0.37122 \\
Salinity & $\mathbf{0 . 8 9 1 3 9}$ & -0.26001 & -0.37124 \\
Turbidity & $\mathbf{0 . 9 1 9 9 4}$ & 0.34943 & 0.17780 \\
Eigen Value & 13.60 & 6.28 & 4.05 \\
Variability (\%) & 48.83 & 22.42 & 14.50 \\
Cumulative (\%) & 48.83 & 71.25 & 85.75 \\
\hline Bum & & &
\end{tabular}

Bold values $>0.5$ are significant

\section{CONCLUSION}

In this study, multivariate statistical technique was used to evaluate temporal variations in the surface water quality of Merbok River. PCA was successfully applied which identified the dominant parameters responsible for the major water quality variation and their possible sources in the study periods. There were differences in the distribution of the elements and physico chemical parameters which were mainly due to inputs from industrial wastes, agrochemicals, inflow of domestic effluents/overland runoff, and weathering processes. Toxic metals such as $\mathrm{As}, \mathrm{Cr}$, and $\mathrm{Pb}$ were much associated with $\mathrm{PC} 1$ and exceeded the reference limits set by INWQS and WHO especially in Aug 2017. Other parameters of interest with concentrations exceeded the recommended guidelines include $\mathrm{NH}_{4}, \mathrm{~F}, \mathrm{Cl}, \mathrm{NO}_{3}, \mathrm{SO}_{4}$ and $\mathrm{PO}_{4}$. Pollution by organic matter and chemically oxidizable substances were also discovered in which BOD, DO, and COD were very significant. The detection of $E$. coli and coliform bacteria as microbial contaminants in the river water indicate the extent of human health risks due to potentially pathogenic microorganisms. To sum, the present study precisely identified the pollutants in Merbok River and highlight the needs of a proper and frequent monitoring for appropriate environmental protection and enforcement.

\section{ACKNOWLEDGEMENT}

This research work was supported by the Ministry of Education Malaysia (MOE) under the Fundamental Research Grant Scheme (FRGS 2016-0085-102-02). 


\section{REFERENCES}

Ahmad, N., Jaafar, M. S., Alsaffar, M. S. 2015a. Study of radon concentration and toxic elements in drinking and irrigated water and its implications in Sungai Petani, Kedah, Malaysia. J. Rad. Res. App. Sci. 8, 3, 294-299.

Ahmad, N., Jaafar, M., Alsaffar, M. 2015b. Natural radioactivity in virgin and agricultural soil and its environmental implications in Sungai Petani, Kedah, Malaysia. Pollution, 1, 3, 305-313.

Ahmed, A. M. 2017. Prediction of dissolved oxygen in Surma River by biochemical oxygen demand and chemical oxygen demand using the artificial neural networks (ANNs). J. King Saudi Univ-Eng. Sci. 29, 2, 151158.

Alsaffar, M. S., Suhaimi, J. M., Ahmad K. N. 2016. Evaluation of heavy metals in surface water of major rivers in Penang, Malaysia. Int. J. Environ. Sci. 6, 5, 657-669.

American Public Health Association. 1995. Standard methods for the examination of water and wastewater, 19th ed. American Public Health Association, Washington, D. C.

ATSDR, 2013. Chromium Toxicity: what Are the Physiologic Effects of Chromium Exposure?

Bridha, K., Elango, L. 2011. Fluoride in groung water: causes, implications and mitigation measures. Fluoride properties, applications and environmental management. 1, 111-136.

Butera, S., Trapp, S., Astrup, T.F., Christensen, T.H. 2015. Soil retention of hexavalent chromium released from construction and demolition waste in a road-baseapplication scenario. J. Hazard. Mater. 298, 361e367.

Cerling, T. E., Pederson, B. L., Von Damm, K. L. 1989. Sodium-calcium ion exchange in the weathering of shales: Implications for global weathering budgets. Geology, 17, 6, 552-554.

Chaurasia, M., Pandey, G.C. 2007. Study of physico-chemical characteristics of some water ponds of Ayodhya-Faizabad. Indian J. Environ. Prot. 27, 11, 1019-1023.

Chen, T., Chang, Q., Liu, J., Clevers, J., Kooistra, L. 2016. Identification of soil heavy metal sources and improvement in spatial mapping based on soil spectral information: a case study in northwest China. Sci. Total Environ. $565,155 \mathrm{e} 164$.

Feng, P., Weagant, S. D., Grant, M. A., Burkhardt, W., Shellfish, M., Water, B. 2002. BAM: Enumeration of Escherichia coli and the coliform Bacteria. Bacteriological analytical manual. 13-19.

Fuge, R. 2018. Fluorine in the environment, a review of its sources and geochemistry. Appl. Geochem. 100, 393-406.

Frampton, E. W., Restaino, L., N. Blaszko, N. 1988. Evaluation of the bglucuronidase substrate 5-bromo-4-chloro-3-indolyl-b-D-glucuronide (XGLUC) in a $24 \mathrm{~h}$ direct plating method for Escherichia coli. J. Food Prot. $51,402-404$.

Happonen, M., Koivusalo, H., Malve, O., Perkola, N., Juntunen, J., Huttula, T. 2016. Contamination risk of raw drinking water caused by PFOA sources along a river reach in south-western Finland. Sci. Total Environ. 541, 7482.

Haris, H., Omar, W. M. W. 2007. Water Quality Status of Petani River Basin Based on Water Quality Index and Physico-Chemical Properties. The 2nd regional conference on ecological and environmental modelling 2007 (ecomod 2007), Penang, Malaysia. 01-18.

Hossain, D., Islam, M. S., Sultana, N., Tusher, T. R. 2013. Assessment of iron contamination in groundwater at Tangail municipality, Bangladesh. $J$. Environ. Sci. Nat. Resour. 6, 1, 117-121.

Ismai'1, W. R., Ibrahim, I. M. N., Willy, R. 2015. Developmental pressure and nutrient concentrations of sungai Petani catchment, kedah Proceedings of the International Conference on Development and Socio-Spatial Inequalities (ICDSSI2015) Universiti Sains Malaysia, 19-20 August, 2015.

Jamieson, R. C., Gordon, R. J., Tattrie, S. C., Stratton, G. W. 2003. Sources and persistence of fecal coliform bacteria in a rural watershed. Water Qual. Res. J. 38, 1, 33-47.
Juahir, H., Zain, S. M., Yusoff, M. K., Hanidza, T. T., Armi, A. M., Toriman, M. E., Mokhtar, M. 2011. Spatial water quality assessment of Langat River Basin (Malaysia) using environmetric techniques. Environ Monit Assess., 173, 1-4, 625-641.

Kamrudzaman A. N., Nordin A. M. A., Aziz R. A., Jali M. F. A. 2012. Mapping Status for River Water Quality Index of Sungai Merbok, Kedah, Malaysia. Int. J. Chem. Environ. Eng. 3, 1, 64-68.

Koki, I. B., Low, K. H., Juahir, H., Azid, A., Zain, S. M. 2017. Assessment of water quality of man-made lakes in Klang Valley (Malaysia) using chemometrics: the impact of mining. Desal Water Treat, 74, 125-136.

Kozaki, D., Ab. Rahim, M. H., Wan Ishak, M. F., Yussoff, M. M., Mori, M., Nakatani, N., Tanaka, K. 2016. Assessment of the river Water Pollution levels in Kuantan, Malaysia, Using ion-exclusion chromatographic data, Water Quality indices, and land Usage Patterns. Air, Soil Water Res. 9, 0111.

Low, K. H., Koki I. B., Juahir, H., Azid, A., Behkami, S., Ikram, R., Mohammed, H. A., Zain S. M. 2016. Evaluation of water quality variation in lakes, rivers, and ex-mining ponds in Malaysia, Desal. Water Treat. 57, 58, 28215-28239.

Ip, Y. K., Chew, S. F., Randall, D. J. 2001. Ammonia toxicity, tolerance, and excretion. Fish physiol., 20, 109-148.

Mansor, N. S., Zulhaidi, H., Shafri, M., Mansor, S., Paradhan, B. 2014. The influence of urban development and social mobility on socioeconomic level: The application of GIS on urban ecosystems. Earth and Environ. Sci. 20, 01-07.

Mearns, A. J., Reish, D. J., Oshida, P. S., Ginn, T., Rempel-Hester, M. A., Arthur, C., Rutherford, N. Pryor, R. 2015. Effects of pollution on marine organisms. Water Environ. Res. 87, 10, 1718-1816.

Mor, S., Ravindra, K., Dahiya, R. P., Chandra, A. 2006. Leachate characterization and assessment of groundwater pollution near municipal solid waste landfill site. Environ. Monit. Assess. 118, 1-3, 435-456.

Nor Farhanna M., Ahmad, Z. A., Sarva, M. P. 2015. Preliminary study of heavy metal $(\mathrm{Zn}, \mathrm{Pb}, \mathrm{Cr}, \mathrm{Ni})$ contaminations in Langat River estuary, Selangor. Proc. Environ. Sci. 30, 285-290.

Pereira, W. E., Hostettler, F. D. 1993. Nonpoint source contamination of the Mississippi River and its tributaries by herbicides. Environ. Sci. Technol. 27, 8, 1542-1552.

Ruiz-Agudo, E., Mees, F., Jacobs, P., Rodriguez-Navarro, C. 2007. The role of saline solution properties on porous limestone salt weathering by magnesium and sodium sulfates. Environ. Geol. 52, 2, 269-281.

Sharip, Z., Jusoh, J. 2010. Integrated lake basin management and its importance for Lake Chini and other lakes in Malaysia. Lakes Reserv: Res. Manag. 15, $1,41-51$.

Sibal, L. N., Espino, M. P. B. 2018. Heavy metals in lake water: a review on occurrence and analytical determination. Int. J. Environ. Anal. Chem. 98, 6, 536-554

Simeonov, V., Stratis, J. A., Samara, C., Zachariadis, G., Voutsa, D., Anthemidis, A., Sofoniou M., Kouimtzis, T. 2003. Assessment of the surface water quality in Northern Greece. Water Res. 37, 17, 4119-4124.

Wang, H., Malhotra, S. V., Francis, A. J. 2011. Toxicity of various anions associated with methoxyethyl methyl imidazolium-based ionic liquids on Clostridium sp. Chemosphere, 82, 11, 1597-1603.

Wong, C. L., Venneker, R., Uhlenbrook, S., Jamil, A. B. M., Zhou, Y. 2009. Variability of rainfall in Peninsular Malaysia. Hydrol. Earth Syst. Sc. 6, 4, 5471-5503.

Zain, S. M., Behkami, S., Bakirdere, S., Koki, I. B. 2016. Milk authentication and discrimination via metal content clustering - A case of comparing milk from Malaysia and selected countries of the world. Food control, 66, 306314. 